\title{
ブロックゲージの引張力の解析 ${ }^{*}$ \\ 一ブロックゲージの密着力に関する研究 (第 3 報 $)$ —
}

\author{
津 村喜 代 治** 藤 井 康 治*** \\ Analysis of Tensile Strength of Block Gauges \\ - Study on Wringing Force of Block Gauges (Report 3)-_
}

Kiyoji Tsumura, Yasuharu FujII

When block gauges wrung together are pulled from each other in the direction perpendicular to the wringing surface, the maximum force required to separate them is termed tensile strength. Although there are reports on qualitative study of this strength, these seems to be none that deals with its theoretical analysis.

This report gives analysis of tensile strength and presents the causes of this strength. The findings are summarized as follows:

1. Tensile strength is considered attributable to viscosity and surface tension of oil trapped between the wringing surfaces.

2. Tensile strength is not suitable as a force for evaluating wringing force as it is greatly influenced by oil distribution between the wringing surfaces.

\section{1. まえがき}

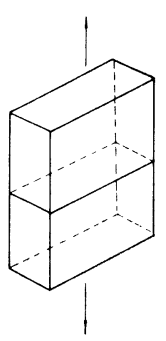

图 1 污張力
ブロックゲージを密着させ図 1 に示

すように密着面に対して垂直に引張,

て，密着をはずすに必要な力を一般に 引張力と呼えでいる.この引張力には 力安作用させると同時に密着のはずれ るときの力と一定速度で力をしだいに 増加させて, 密着がはずれるときのノ の最大值で表示する 2 種類が考えられ

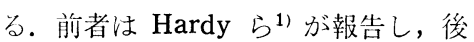
者は一般の概念として採用されているカである.

この引張力については Bowden ら ${ }^{2)}$ の研究がある. 密 着現象を理論的に解析しているが, 実験值と計算值とに は大きな差が認められる。 またこの力については多くの 実験者による報告があるが，同じ油を使用した条件でも $4 \sim 60 \mathrm{~kg} / \mathrm{cm}^{2}$ と広範囲にわたっている.

このため諸国家のブロックゲージの規格について密着 に関する項目はほとんよ゙定性的な規定にとよ゙ま,ててる ようである。

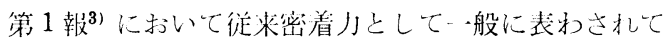
いる引張力に㳔倩力が含ま机ているものであること在 明らカルした。この報では引偯力から付着力花減じた力

*原稿受付 昭和45年 9 月 25 日. 昭和45年度精機学会春季大 会学術講演会（昭和45年 4 月 3 日）にて発表.

**正 会 員 東洋工業(株)（広島市外府中町）

***正 会 員 東北大学工学部（仙台市荒巻字青葉）
を動的付着力と呼ぶことにし，この力は密着面間に介在 する油の战怟抗によるものと考えられることを明らか にした。

\section{2. 引張力の解析}

\section{1 引張力の定義}

将さhの油膜をはさんで 1 組のブロックゲージを上下 に置き，上のブロックゲージを上方に引張り，下のブロ ックゲージに作用する力を抵抗線ひずみ計を利用した荷 重変換器により測主した結果を図 2 に示してある.

区間A B 注 $h$ の油膜の厚さに対する付着力を指示して いる.

点 $\mathrm{B}$ は急に上のブロックゲージを上方へ引張った点で 力は急激に増加する。

区間 B D は上のブロックゲージを上方へ引張っている ときで, 力はC点でピークになった後しだいに減少す る.

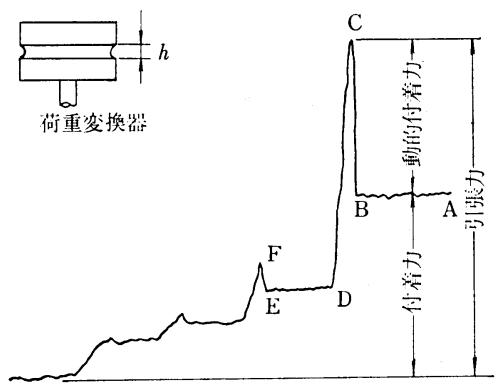

図 2 引張力の定義 


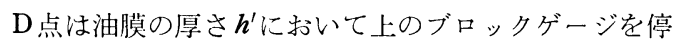
止した点である。

区間 $\mathrm{DE}$ \&油膜の厚さ $h^{\prime}$ に対する付着力を指示してい る.

ピークの力は従来引張力とよばれているもので, 付着 力が含まれていることがわかる. この引張力と付着力と の差を動的付着力と呼ぶことにし，この力について解析 を行なう。

\section{2 動的付着力の解析}

ブロックゲージの密着面間に油の介在している状態お よび上のブロックゲージを上方へ引張り, 油膜の変形し た状態を仮定して図 3 に示してある.ブロックゲージを 上方へ引張ると油膜注矢印のように油膜の中心移動す る.この油の流れには粘性による抵抗が伴うと考元ら れ，動的付着力はこの抵抗に起因するものと仮定して， 理論的にその大きさを解析してみる.

上下のブロックゲージの細隙に介在する油が矢印の方 向へ移動する状態抄よび動的付着力を解析するために必 要な諸元を図 4 に示してある. この図において油の粘性 係数をク, 密着面に垂直な方向の速度こう配を $d v / d x$, 粘性により伴う抵抗力を $F_{1}$ とすれば, $F_{1}$ 沈式(1)で与元 られる.

$$
F_{1}=2 b d l \eta \frac{d v}{d x}
$$

他方油膜 $\mathrm{AB}, \mathrm{CD}$ の両側面間の压力差を $\Delta p$ とし,こ の压力差により生ずる力を $F_{2}$ とすれば， $F_{2}$ は

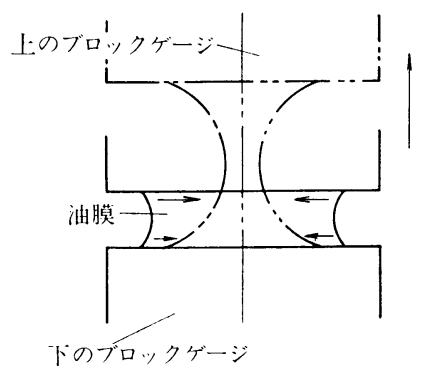

図 3 油の挙動の説明図

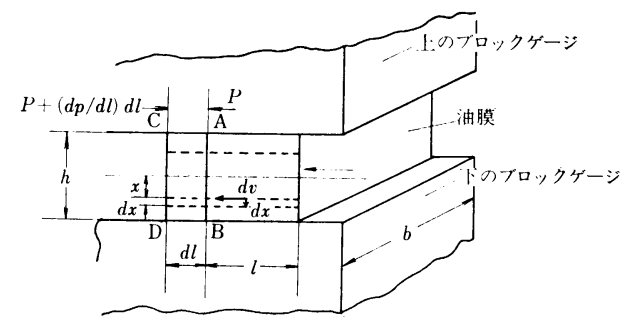

図 4 油膜の移動の抵抗力の解析図

$$
F_{2}=2 b x \Delta p
$$

となる.

$d v / d x$ 注であるから， $F_{1}$ と $F_{2}$ との静的釣合は

$$
-2 b d l \eta \frac{d v}{d x}=2 b x \Delta p
$$

となる。ゆえに

$$
d v=-\frac{\Delta p}{\eta d l} x d x
$$

となる，この式を積分し，境界条件 $x= \pm h / 2$ のとき $v$ $=0$ を代入すると， $v$ は

$$
v=\frac{\Delta p}{2 \eta d l}\left(\frac{h^{2}}{4}-x^{2}\right)
$$

となる. $x=0$ のときの $v$ の值を $v_{0}$ とすれば, $v_{0}$ は

$$
v_{0}=\frac{\Delta p h^{2}}{8 \eta d l}
$$

となる。

図 4 を参照す机ば，圧力差 $\Delta p$ は

$$
\Delta p=p-\left[p+\left(\frac{d p}{d l}\right) d l\right]=-\left(\frac{d p}{d l}\right) d l
$$

となる、 $\Delta p$ を式(3)に代入すれば， $v_{0}$ は式(4)になる.

$$
v_{0}=-\frac{h^{2}}{8 \eta} \frac{d p}{d l}
$$

油膜の断面形状を円形と仮定すると, 图 5 を参照して $d p / d r$ は正であるから, $v_{0}$ は

$$
v_{0}=\frac{h^{2}}{8 \eta} \frac{d p}{d r}
$$

となる、ゅえに

$$
d p=\frac{8 \eta v_{0}}{h^{2}} d r
$$

となる，この式を積分し，r=Rのとき $p=0$ であるから 流体压力 $p$ 沫

$$
p=\frac{8 \eta v_{0}}{h^{2}}(r-R)
$$

となる。この流体圧力 $p$ の平均值を $p_{m}$ とすれば， $p_{m}$ は

$$
p_{m}=-\frac{8 \eta v_{0}}{3 h^{2}} R
$$

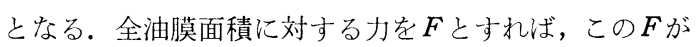

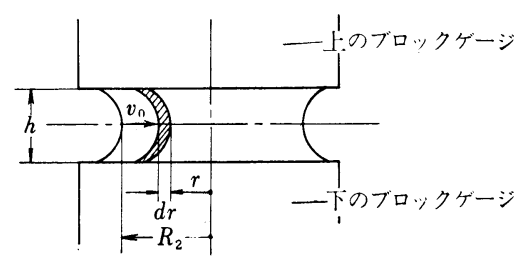

図 5 油膜の移動速度の解析図 


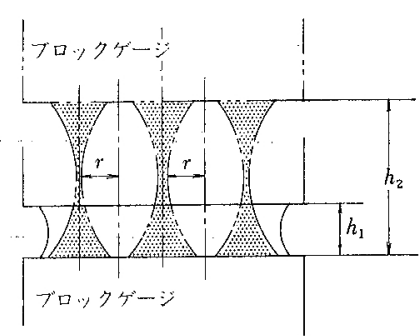

図 6 密着面の油の挙動についての仮定

ブロックゲージを上方に引張るときの抵抗力となると考 光られる。光にF注

$$
F=\pi R^{2} p_{m}=-\frac{8 \pi \eta v_{0} R^{3}}{3 h^{2}}
$$

となな。

上のブロックダージを上方に偯り，密着のばずれた ときの密着面学推測した結果，油の举動推測して模型 的に図 6 K示してある. 部分的に集合した油膜の形状， 大きさはおのおの等しいと仅定し, 油营の厚さ $h_{1} か ら h_{2}$

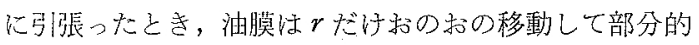
に集合したとする。このときの所要時閒を $t$ とする.

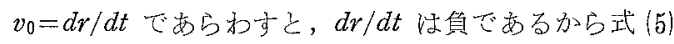
忙

$$
d t=\frac{8 \pi \eta R^{3}}{3 h^{2} \bar{F}} d r
$$

上なる.兑に

$$
t=\frac{8 \pi \eta R^{3}}{3 h^{2} F} \int_{0}^{r} d r=\frac{8 \pi \eta R^{3} \gamma}{3 h^{2} F}
$$

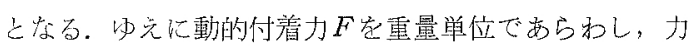

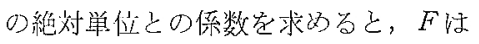

$$
F=\frac{8 \pi \eta R^{8} r}{3 h^{2} t} \times 10^{-6}
$$

七店等.

$$
\text { ここにクは酒の粘性係数 }
$$

$R$ ほ密着したときの油膜の半径 r滵着のはずれるまでの油の最大移動 距離 ん証密着したときの油膜の厚さ (cm) $t$ 滵着のはずれるまでの時間

である。

\section{3 引張力}

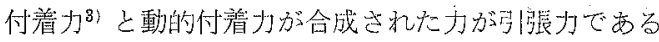
ので，この司脸力を $F_{t}$ とす扎ば， $F_{t}$ は

$$
F_{t}=\left(\frac{2 \pi R^{2} \sigma \cos \theta}{h}+\frac{8 \pi \eta R^{3} r}{3 h^{2} t}\right) \times 10^{-6}
$$

上度当。

ここに $\sigma$ 恃表面張力

$(\mathrm{dyn} / \mathrm{cm})$ $\theta$ 注接触侍

である。

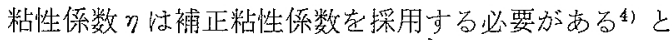
思われるので，䋠正係数军 $\alpha$ とすればFt性

$$
F_{t}=\left(\frac{2 \pi R^{2} \sigma \cos \theta}{h}+\frac{8 \pi \alpha \eta R^{3} r}{3 h^{2} t}\right) \times 10^{-6}
$$

となる。

\section{3. 引張力の解析の裹付基礎実験}

ブロックゲージを密着した場合油膜の厚さ，油膜の分 布斗径など学正確に測定することは困難である。ゆ光に これらが高精度に測定できる領域すなわち油脭の掌さ $20 \mu$ 以上の条件に就いて実呀定行ない，引張力の解析定 裏付けて多。.

\section{1 基礎実験装置と方法}

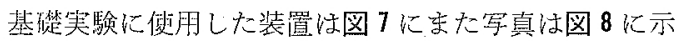
してある。図に扔いて右側のブロックゲージは心押台側 の測定子に取付けてある。莎重变換器は測定大ピンドル の先端に圆定され，左側のプロッタゲージはこの变換器 のロッドに取付けてある。

油獏の厚さは測定スピンドルの移動量を読取る測微顕 微鏡により測定し, 油荧の分布半径は測定テーブルの上 に図に示すような顕微鏡を别に固定し，この顕微鏡とテ ーブルの移動量它読取る゙マイタロメーターッドと等併用 して測定した。

测定スピンドルは電動機により一定速度で移動させ る. 実験に使用した装置の仕様性表 1 に示してある. 使

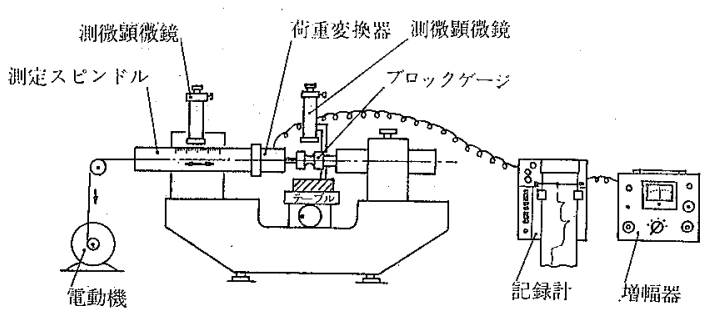

图 7 基礎実験装置

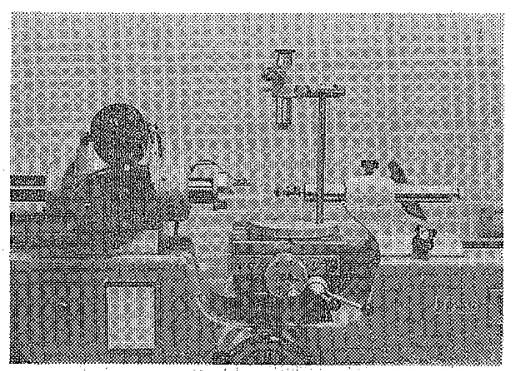

図 8 基礎害験装置の写唭 
用したブロックゲージは呼び寸泣 $5 \mathrm{~mm}$ で，密着面の精 度は JIS B 7506 A 級に相当与るものである。密着に使 用した油の種類と特性は表 2 に示してある。

\section{2 基礎実験の結果}

油膜の厚さを $30 \mu$ から $10 \mu$ とびに段階的に一定速度 で変化させて，引張力を測定したときの油膜の厚さと引 張力との関係の実験結果は図 9, 10 に示してある.

この図において式(7)に実験の諸条件岁代入して求めた 計算值を示してあるが，実験值とほぼ一致していること が認められる。しかしこの計算值は接触角 $\theta$ を 85 度と

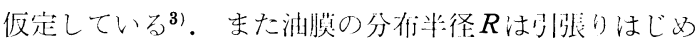
て引張力の植大值のあらわ扎る点までは变化しないこと が観測されたので，引张りはじめに測定した值を採肘し た。

\section{4. 実用条件の実験}

油膜の厚さ $20 \mu$ 以上の密着条作で行なった宦験結果 と計算值とはほぼ一致することが涊められた。ここでは 油膜の厚さ $0.02 \sim 0.05 \mu$ 程度の密着の尖朋条件に抄い

表 1 奠験装置の仕様

\begin{tabular}{|c|c|c|}
\hline 品名 & 製 你 所 & 式 \\
\hline 荷重変換器 & 其: 和 電 業(株) & $120 \mathrm{~T} \cdot 2000 \mathrm{~A}$ \\
\hline 増 幅 器 & 11 & DPM -1 \\
\hline 記 録 計 & シチズン時計·(株) & TRE 5 \\
\hline 測 長 機 & Carl Zeiss & U.H.M \\
\hline 測微顕微鏡 & 東京光 学:(株) & MM \\
\hline
\end{tabular}

表 2 坚験て使用した油の特性:

\begin{tabular}{|c|c|c|}
\hline & $\mid \begin{array}{c}\text { 表面張力 } \\
(\mathrm{dyn} / \mathrm{cm})\end{array}$ & $\begin{array}{c}\text { 粘性係数 } \\
\text { (poise) }\end{array}$ \\
\hline グ リ セ リン & 63.4 & 1.2 \\
\hline エチレングリコール & 47.7 & 0.2 \\
\hline スピンドル油 & 31.1 & 0.2 \\
\hline ひ ま し 油 & 36.5 & 4.3 \\
\hline さび 止 め 油 & 34.0 & 3.5 \\
\hline
\end{tabular}

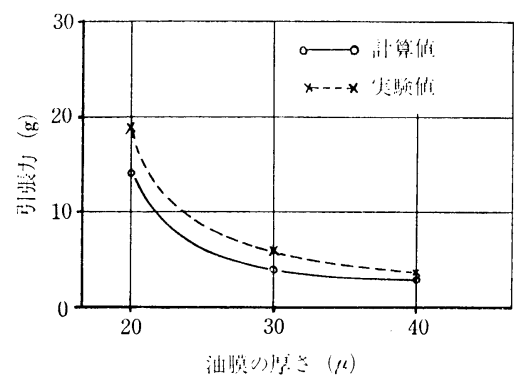

図 9 油膜の澋さと引張力との関倸（さび止め油）

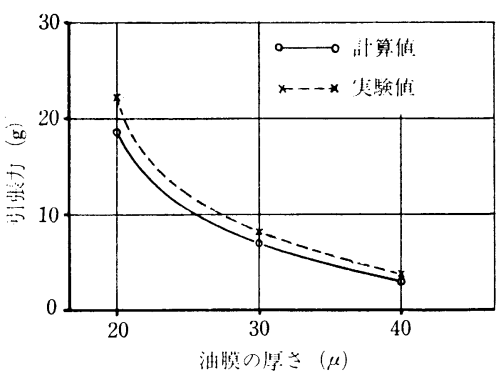

図 10 油膜の厚さと引張力との関係（ひまし油）

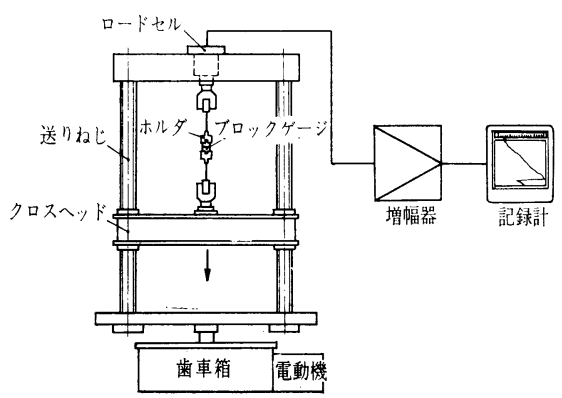

図 11 引㖘試験機の構造
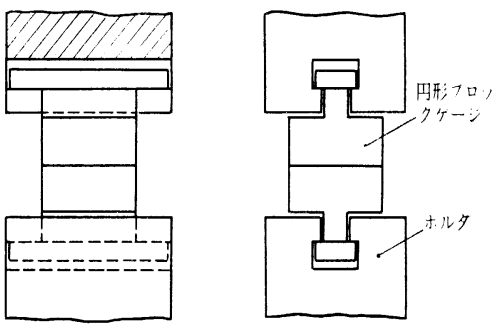

図 12 ブロックゲージ，ホルダ形状

て，赺験值と郭算值とが一致与るか否か確吣してみた。

\section{1 実験装置および方法}

この実験は材料試験機を利用して行なった。この試験 機の構造を模型的に図 11 に示してある.

この庹に扮いて送り袮じの回転によりクロスヘッドを 矢印の力向に移動させ，ブロックゲージを引躴り，この 時の力をロード七ルにより測定する。

笑験に使用したブロックゲージは式(8)において断面形 状劣円形として解析している関係から図 12 に示与よう な形状のもの老使用した。ブロックゲージの円形状密着 面の文対側はT形の形状をしている。またブロックゲー ジを保持するホルダはT形しみだがあり，ブロックゲー ジをこのみぞにさし込むう式とし，締付けにより密着面 平面が変形与る问能性の亦る機械的締付方法をさけた。 油膜の厚さは第，2報4ににおいて述べた方法により測主 
表 3 引張力の実験結果 (さび止め油)

\begin{tabular}{c|c}
\hline $\begin{array}{c}\text { 譚 值 } \\
(\mathrm{kg})\end{array}$ & $\begin{array}{c}\text { 筷 } \\
(\mathrm{kg})\end{array}$ \\
\hline 18.4 & 21.0 \\
14.5 & 20.3 \\
16.5 & 21.0 \\
20.2 & 13.5 \\
\hline
\end{tabular}

Lた.

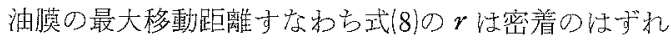
たときの密着面に付着している油の分布状態位相差顕 微鏡により観測して求めた。

\section{2 害験結果}

実駼の記録例括よび密着のはずれたときの密看面に分 布した油膜の状態老和のおの図 13 (a)，(b)，14(a)，(b) に示してある。この四加ら図 6 亿示した油膜の最大移動 距離 $r$ を求め, 密着したときの油膜の分布半径 $R$ は試料

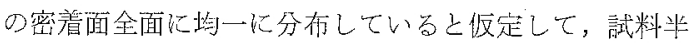
径の值を採用した。 またその他の実験の諸条件を式(8)に

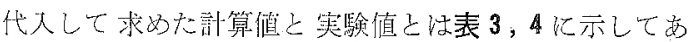
る.この表から見るとかなり一致しているものも，相虺 しているものむ洒められる。

この原因についてはつぎのよらに将交ら秃る。式(8)

示した符 2 項の動的付着力は油膜の分布半径の 3 乗, 油 膜の厚さの 2 乘に関係してくる。このため実験の苁件と 計算した策件との差が大きく影響してくる。安た実駼中 の微小振動, 密着面に対して芫全に直角に引張っている かなどーすね方折離力が働き，司張力の測定值它低下さ

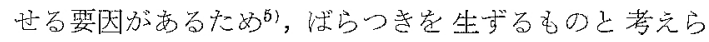
东る。

\section{5. 油膜の厚さと引張力との関係}

断面形状が長方形のブロックグージにより油膜の厚さ

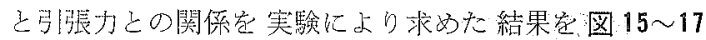
に亦してある。

この园から見て明らかなるうに同じ油膜の厚さでも引

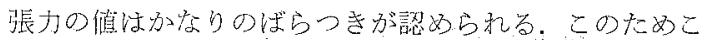
の力滵着性定評洒する打として壮不適当であると考光 ら厹。

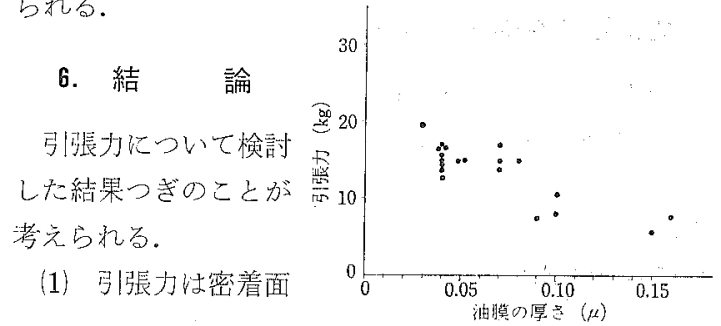

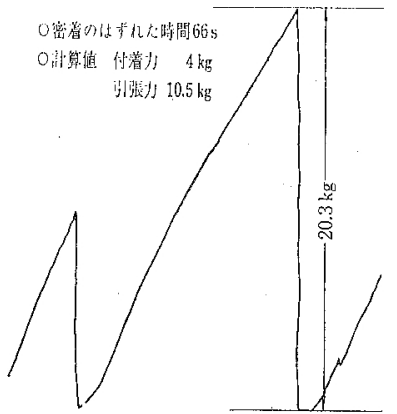

図 13 (a) 実験記鉎例（さび止め油）

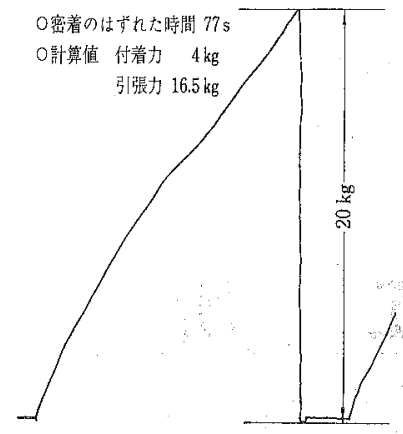

图 14 （a） 実験記録例(ひまし油)

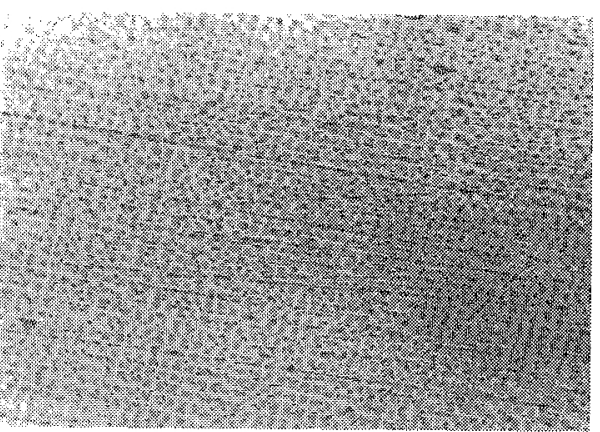

图 13 (b) 密流面の油の分布状態(さび止沙油) $\times 500 R=0.9 \mathrm{~cm}, r=2 \mu, h=0.05 \mu$

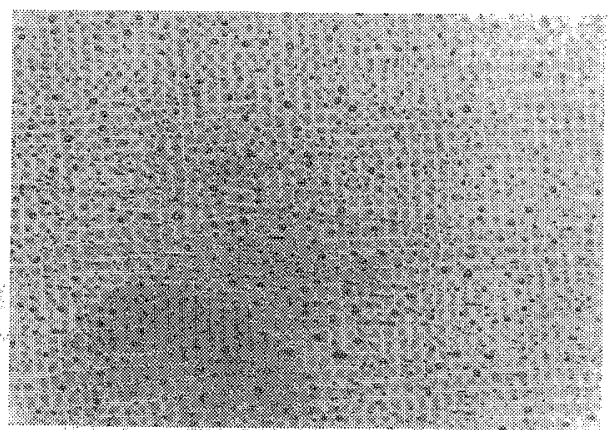

図 14 (b) 密着面の油の分布状態(屾しし油) $\times 500 R=0.9 \mathrm{~cm}, r=4 \mu, h=0.05 \mu$

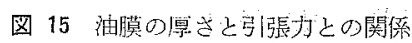
(さび止齐油)

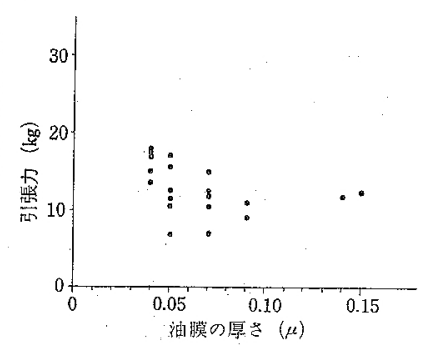

図 16 油膜の厚さと引張力との関倸 (ひまし涆)

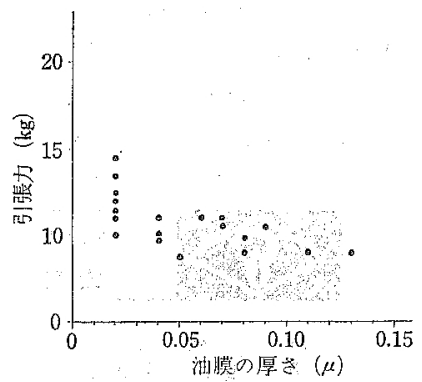

图 17 油膜の厚さと引張力との関倸 (スピンドル油) 
間に介在する油の表面張力と粘性によるものと考 えられ，この力は式(8)で近似的に評価することが できる.

（2）引張力は密着面間に介在する油の分布条件，力の 測定条件などに大きく影響されるため, 密着性を 評価する力としては不適当である.

\section{文献}

1) W.B. Hardy, M. Nottage: Studies in Adhesion I,
Proceedings of Royal Society of London, (Sec. A), 112 (1926) 606.

2) F.P. Bowden, D. Tabor: Friction and Lubrication of Solids, OxFord at the Clarendon Press, (1954) 304.

3) 藤井, 津村：ブロックゲージの付着力について, 精密機械, 37, 7 (1971) 33.

4) 藤井, 津村：ブロックゲージの接線抵抗力について, 精密 機械, 37, 10 (1971) 15.

5）津村：ブロックゲージの密着に関する研究 (第 2 報), 精 機学念東北支部講演会前刷 (1967).

\section{一表紙写真説明——}

\section{H45 円筒研削盤高速研削仕様シリーズ}

$30 \mathrm{~m} / \mathrm{s}$ から $45 \mathrm{~m} / \mathrm{s}$ ヘスピードァップ

H 45 高速研削仕様シリーズは生産性を高め, 加工精度を向上させます.

大隈の新シリーズ円筒研削盤は, 低温度上笲の新形砥 石軸の採用, 大重量砥石の高速運転にも十分耐える剛性 の高い砥石台, ベッドの構造により，標準形円筒研削盤 と间一ベースマシンを用い，ブロックビルド方式にて全 機種高速研削仕様上することができます。

\section{仕様の概略説明}

1 大隈の円筒研削盤忖ざて H45 高速研削仕様シリ一 ズとすることができます（表参照）。

2 研削液の種類（水溶性または不水溶性）ならびに供給 量, 厷力により高速研削作業の成果が大きく左右さ机 ま寺。

$3 \mathrm{H} 45 \mathrm{~A}$ 仕様は砥们周速のみを $45 \mathrm{~m} / \mathrm{s}$ の仕様とした もので, その他は標準仕様でありま与。水溶性研削液

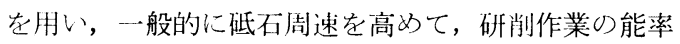
をあげることを目的としたものであります。

$4 \mathrm{H} 45 \mathrm{~B}, \mathrm{H} 45 \mathrm{P}$ 仕様は, 単一部品多量生産作業の高能 率化を計るためのものであり, 砥石周速は $45 \mathrm{~m} / \mathrm{s}$ であります。適用研削液は $\mathrm{H} 45 \mathrm{~B}$ 仕様が水溶性, $\mathrm{H}$ $45 \mathrm{P}$ 仕様が不水溶性と 2 理類の仕様があります.

5 取りしろ $1 \mathrm{~mm} \phi$ 程度までの場合には，いずれの仕様 も使用できますが，精度が重点になる場合には水溶性
研削液を用いる $\mathrm{H} 45 \mathrm{~B}$ 仕㥞が適しております。 0.5 $\mathrm{mm} \phi$ 程度までの普通取りしろの場合にはこの仕様て もかなりの成果を期待できます。

6 高取りしろ作業に高度な高能率を期待する場合には H $45 \mathrm{P}$ 仕様が適します。

7 主軸台は機種により各種形式のものがあります.

$8 \mathrm{H} 45$ 高速研削仕㥞シリーズ用の低石は当該工作物汇打 ける従来の砥石納入メ一カに対し, 作業内容目的なよ゙ をご指示のうえ，低石製造の可否を，打打合わせされ て直接ご購入ください.

9 低石モータ出力は作業内容に合わせて決めさせていた だきます。

\section{H 45 高速研削仕様シリーズ適用機種}

\begin{tabular}{|c|c|c|c|c|c|c|c|}
\hline \multirow{2}{*}{\multicolumn{2}{|c|}{ 分 類 }} & \multirow[t]{2}{*}{ 機 } & \multirow[t]{2}{*}{ 種 } & \multirow{2}{*}{$\begin{array}{l}\text { 駆動 } \\
\text { 方式 }\end{array}$} & \multicolumn{3}{|c|}{$\begin{array}{l}\text { 適用可能なH45高 } \\
\text { 速研削仕様シリーズ }\end{array}$} \\
\hline & & & & & $\mathrm{H} 45 \mathrm{~A}$ & $\mathrm{H} 45 \mathrm{~B}$ & $\mathrm{H} 45 \mathrm{P}$ \\
\hline \multirow{2}{*}{\multicolumn{2}{|c|}{ 万 能 形 }} & G U & 30 & 油压 & & - & - \\
\hline & & $\mathrm{GU}$ & $33,40,55$ & 油圧 & & - & - \\
\hline \multirow{3}{*}{\multicolumn{2}{|c|}{ 標準筒形 }} & GP & 30 & 油压 & & - & - \\
\hline & & $\mathrm{GC}$ & 30 & 油压 & & & 0 \\
\hline & & G P & $33,40,55$ & 油压 & & 0 & 0 \\
\hline \multirow{3}{*}{$\begin{array}{l}\text { プッ } \\
\text { ラト } \\
\text { ソ専 } \\
\text { ジ用 } \\
\text { カ機 }\end{array}$} & 円筒形 & $\mathrm{GC}$ & $33,40,55$ & 電気 & & $\bigcirc$ & 0 \\
\hline & $\begin{array}{l}\text { アス形 } \\
\text { ソラ }\end{array}$ & $\mathrm{GCA}$ & 30 & 油圧 & & & \\
\hline & $\begin{array}{l}\text { グイ } \\
\text { ルド }\end{array}$ & $\mathrm{GCA}$ & $33,40,55$ & 電気 & $\bigcirc$ & 0 & 0 \\
\hline
\end{tabular}

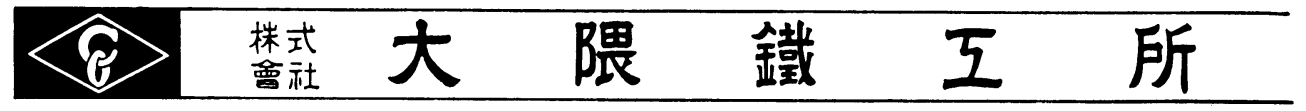

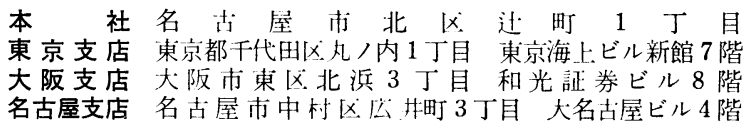

干 462 電話 $<052>911-4111$ (大代表)

兵 100 電話 $<03>2134611$ (代表)

龺 541 電話 $<06 \% 231-0071$ (代表)

$\boldsymbol{\Gamma} 450$ 電話 $<052>561-5571$ (代表) 